\title{
Phytoestrogens for Cancer Prevention and Treatment
}

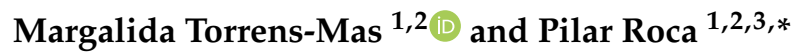 \\ 1 Grupo Multidisciplinar de Oncología Traslacional, Institut Universitari d'Investigació en Ciències de la Salut, \\ Universitat de les Illes Balears, 07122 Palma, Spain; lida.torrens@uib.es \\ 2 Instituto de Investigación Sanitaria Illes Balears, 07010 Palma, Spain \\ 3 Ciber Fisiopatología Obesidad y Nutrición (CB06/03), Instituto Salud Carlos III, 28029 Madrid, Spain \\ * Correspondence: pilar.roca@uib.es; Tel.: +34-971-17184
}

Received: 30 October 2020; Accepted: 25 November 2020; Published: 27 November 2020

Simple Summary: Phytoestrogens are compounds derived from plants that have a similar structure to human sex hormones. This has led to the observation that phytoestrogens have comparable effects to these hormones in our cells. Some beneficial effects of phytoestrogens include the improvement of menopausal symptoms and the prevention of several diseases. In fact, the consumption of soy and soy foods among the Asian population has been associated with a decrease in the incidence of some types of tumors. However, there are some concerns about whether these compounds may also have harmful effects, such as interfere with cancer treatments. In this review, we collect data on the reported effects of phytoestrogens alone or in combination with anti-cancer treatments and discuss the controversy around using these compounds.

\begin{abstract}
Phytoestrogens are a large group of natural compounds found in more than 300 plants. They have a close structural similarity to estrogens, which allow them to bind to both estrogen receptors (ER), ER $\alpha$ and ER $\beta$, presenting a weak estrogenic activity. Phytoestrogens have been described as antioxidant, anti-inflammatory, anti-thrombotic, anti-allergic, and anti-tumoral agents. Their role in cancer prevention has been well documented, although their impact on treatment efficiency is controversial. Several reports suggest that phytoestrogens may interfere with the effect of anti-cancer drugs through the regulation of oxidative stress and other mechanisms. Furthermore, some phytoestrogens could exert a protective effect on healthy cells, thus reducing the secondary effects of cancer treatment. In this review, we have studied the recent research in this area to find evidence for the role of phytoestrogens in cancer prevention and therapy efficacy.
\end{abstract}

Keywords: phytoestrogens; cancer prevention; cancer treatment; antioxidants

\section{Introduction}

Phytoestrogens are naturally occurring compounds in plants and are characterized by a close structural similarity to estrogens. This allows them to act as weak estrogenic factors and interfere with hormonal signaling. Several reports suggest that phytoestrogens may have a positive effect on the prevention of menopausal symptoms, type 2 diabetes, cardiovascular disease, obesity, and cancer. These health benefits are presumably linked to their anti-inflammatory, anti-tumoral, anti-allergic, antioxidant, anti-thrombotic, and hepatoprotective properties [1]. The interest in phytoestrogens and cancer began after the observation that the consumption of soy and soy-derived foods was correlated with a decreased incidence of breast [2], ovarian [3], and prostate cancer [4]. In fact, the levels of genistein, the main soy isoflavonoid, and other phytoestrogens in plasma are inversely correlated to the risk of developing several types of cancer [5-8].

Phytoestrogens have been extensively tested in vitro and in vivo as anti-cancer treatments, although they have also been studied as adjuvant treatments to improve the response to chemotherapy, 
hormonotherapy, and radiotherapy. However, some studies alert that phytoestrogen consumption may interfere with cancer treatments and be harmful to patients. In this review, we analyze the current knowledge of the anti-tumoral properties of phytoestrogens and discuss their potential use as agents for cancer prevention and treatment. For this, we have searched the Pubmed (https: //pubmed.ncbi.nlm.nih.gov/), Google Scholar (https://scholar.google.es/), and Scopus databases (https: //www.scopus.com/home.uri) for articles regarding phytoestrogens and cancer from the last 25 years (1995-2020). To study the combination of phytoestrogens and anti-cancer treatments, especially the last six years (2014-2020) were considered. We also searched clinical trial databases to include those trials, finished or ongoing, using phytoestrogens for cancer patients.

\section{Phytoestrogen Structure and Classification}

Even though phytoestrogens are a large and heterogenic group, all of them are characterized by a phenolic ring and two hydroxyl groups (Figure 1), which are crucial for the binding to the estrogen receptors (ER). The agonist or antagonist properties of phytoestrogens depend on their phenolic group [1]. Based on their structure, phytoestrogens are classified into three main classes, which include flavonoids, lignans, and stilbenes $[9,10]$.

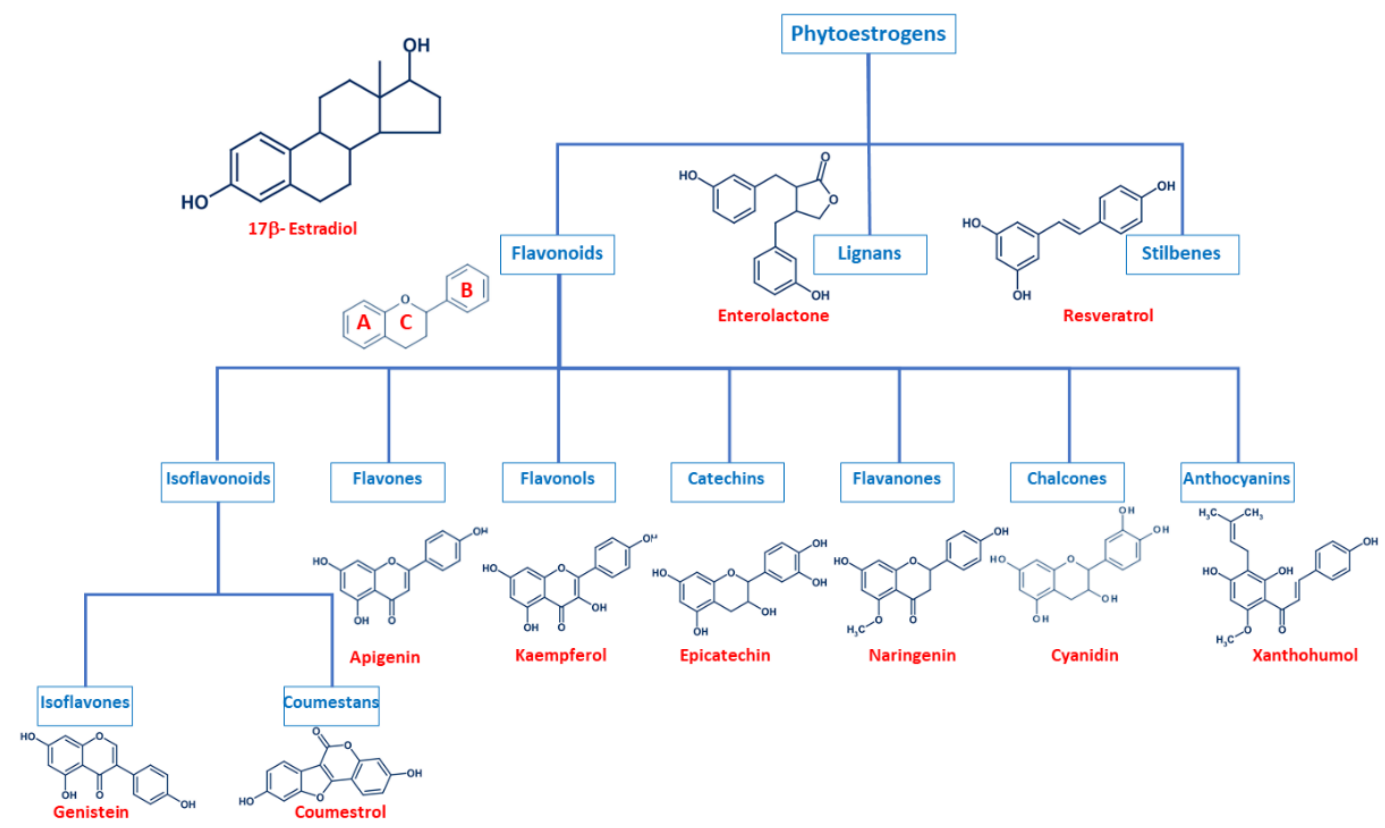

Figure 1. Comparison of the chemical structure of the different classes of phytoestrogens and 17 $\beta$-estradiol.

\subsection{Flavonoids}

Flavonoids present the typical structure $\mathrm{C} 6-\mathrm{C} 3-\mathrm{C} 6$, with two aromatic rings (benzene A and B) joined together by a chain of 3 carbons cycled through an atom of oxygen (Figure 1) [11]. Flavonoids are commonly divided into several sub-classes, based on the connection position of the $B$ and $C$ rings, as well as the degree of saturation, oxidation, and hydroxylation of the $\mathrm{C}$ ring (Figure 1). This subclassification includes isoflavonoids (isoflavones and coumestans), flavones, flavonols, flavan-3-ols (or catechins), flavanones, chalcones, and anthocyanins [1,11-14].

Isoflavonoids are compounds derived from plant metabolism, and their structure consists of a 3-phenylchroman skeleton. They are also divided into two major groups, isoflavones, and coumestans. Isoflavones are flavonoids in which the $\mathrm{B}$ ring is linked to the heterocyclic ring at the $\mathrm{C} 3$ instead of the $\mathrm{C} 2$ position (Figure 1) [15]. Genistein and daidzein constitute up to $90 \%$ of isoflavones found in soybeans [16], and formononetin and biochanin A are mainly found in red clover. Isoflavones can be found in their free form or in their esterified forms [15]. Coumestans, the other subclass of isoflavonoids, have a 1-benzoxolo(3,2-c)chromen-6-one structure formed by a benzoxole fused with a chromen-2-one. 
One of the most studied coumestans is coumestrol, considered an endocrine disruptor, as it has the potential to bind to both ERs with similar affinity as estradiol, affecting the estrogenic signaling cascade [17]. Although the estrogenic activity of coumestrol is weaker than that of estradiol, it is 30 to 100 times greater than that of other isoflavones [18], due to the position of its two hydroxy groups, which match estradiol. This chemical structure also gives coumestrol the ability to inhibit aromatase and $3 \alpha$-hydroxysteroid dehydrogenase [19], which are involved in the synthesis of steroid hormones [20].

Flavones are another type of flavonoids with a double bond between C2 and C3 (Figure 1). Furthermore, the $\mathrm{C} 3$ position does not have any substitution, and C4 is oxidized [21,22]. Luteolin and apigenin are the main compounds in this group. Due to its structure, luteolin is a strong inhibitor of xanthine oxidase, one of the main sources of ROS production [23]. On the other hand, apigenin is thought to protect cells against oxidative damage by enhancing mitochondrial function [23]. Furthermore, flavones may induce cell cycle arrest and DNA damage in some cell types, and specifically, apigenin may trigger apoptosis by inducing the activity of p38 kinase [24].

Flavonols are characterized by a 3-hydroxyflavone skeleton and are classified by the position of their phenolic group (Figure 1). Quercetin and kaempferol are the most predominant flavonols in plants [14]. Catechins or flavanols are mainly found in tea, vinegar, peach, and pome fruits. Epicatechin is an abundant polyphenol in unfermented cocoa beans, and it is thought to be responsible for the main health effects of cocoa. Another widely studied catechin is epigallocatechin gallate (EGCG), which is formed by the ester of epigallocatechin and gallic acid and is present in green tea. Both catechins have been associated with antioxidant and chemopreventive effects in several cell lines [25,26].

Flavanones are found in all citric fruits, and their chemical structure differs from flavones in the saturation of the $C$ ring, with a saturated double bond between positions 2 and 3 (Figure 1) [12]. Naringenin is the most studied flavanone and contributes to limit lipid peroxidation and protein carbonylation by increasing antioxidant defenses [27]. Isoxanthohumol and 8-prenylnaringenin are also flavanones found in hop (Humulus lupulus), and they are also widely studied for their anti-cancer effects [28]. 8-prenylnaringenin has been identified as the most potent phytoestrogen and binds to both ERs [29], and inhibits aromatase [30]. Chalcones also belong to the flavonoids class and have a common 1,3-diaryl-2-propen-1-one skeleton, named chalconoid (Figure 1). The most studied chalcone is xanthohumol, also present in hop plants, and it possesses antibacterial and anti-cancer effects [31]. Finally, anthocyanins are the most abundant flavonoids in fruits and vegetables [32]. They are formed by a flavylium cation (2-phenylbenzopyrilium), which links hydroxyl (-OH) and/or methoxyl (-OCH3) groups. Various anthocyanins have been described, and mainly six are found in vegetables and fruits: pelargonidin, cyaniding, delphinidin, petunidin, peonidin, and malvidin [33].

\subsection{Lignans}

Lignans are another class of phytoestrogens commonly found in grains, nuts, coffee and tea, cocoa, flaxseed, and some fruits [34]. The chemical structure of lignans consists of two phenylpropane groups linked by a $\beta-\beta^{\prime}$ bond, which is formed by a $C-C$ bond between the central atoms of their side chains (position 8 or $\beta$ ) (Figure 1) [35-38]. Some studies report that these phytoestrogens are capable of mimicking the antioxidant effects of some hormones without any associated deleterious effects $[35,39,40]$. Importantly, gut bacteria are responsible for the metabolization of lignans and produce enterodiol and enterolactone. Thus, the beneficial health effects of lignans may be conditioned to each individual's microbiota [41].

\subsection{Stilbenes}

Finally, stilbenes are an important group of nonflavonoid phytoestrogens with a polyphenolic structure with a 1,2-diphenylethylene nucleus (Figure 1) [42]. The most studied stilbene is resveratrol, a compound with two phenolic rings connected by a styrene double bond. This compound can occur in trans- and cis-isoforms, being the trans-isoform the most predominant one [43]. Resveratrol is found in a wide variety of dietary foods, including grapes, wine, nuts, and berries [44,45], and in fact, 
is considered a key compound in the French Paradox [46]. Several in vitro and in vivo studies report that resveratrol has anti-cancer properties, as well as antioxidant, anti-aging, anti-inflammatory and anti-pathogen effects [43-45,47,48].

\section{Mechanism of Action of Phytoestrogens and Cancer Prevention}

It has been established that phytoestrogens interact with ERs, activating the transcription of several target genes. This results in the increase of the levels of antioxidants enzymes, such as superoxide dismutase (SOD), catalase (CAT), and glutathione peroxidase (Gpx), as well as an improvement of mitochondrial function [49-51]. Phytoestrogens also bind to G-protein-coupled estrogen receptor 1 (GPER/GPR30) and exert non-genomic effects [52-54] (Figure 2).

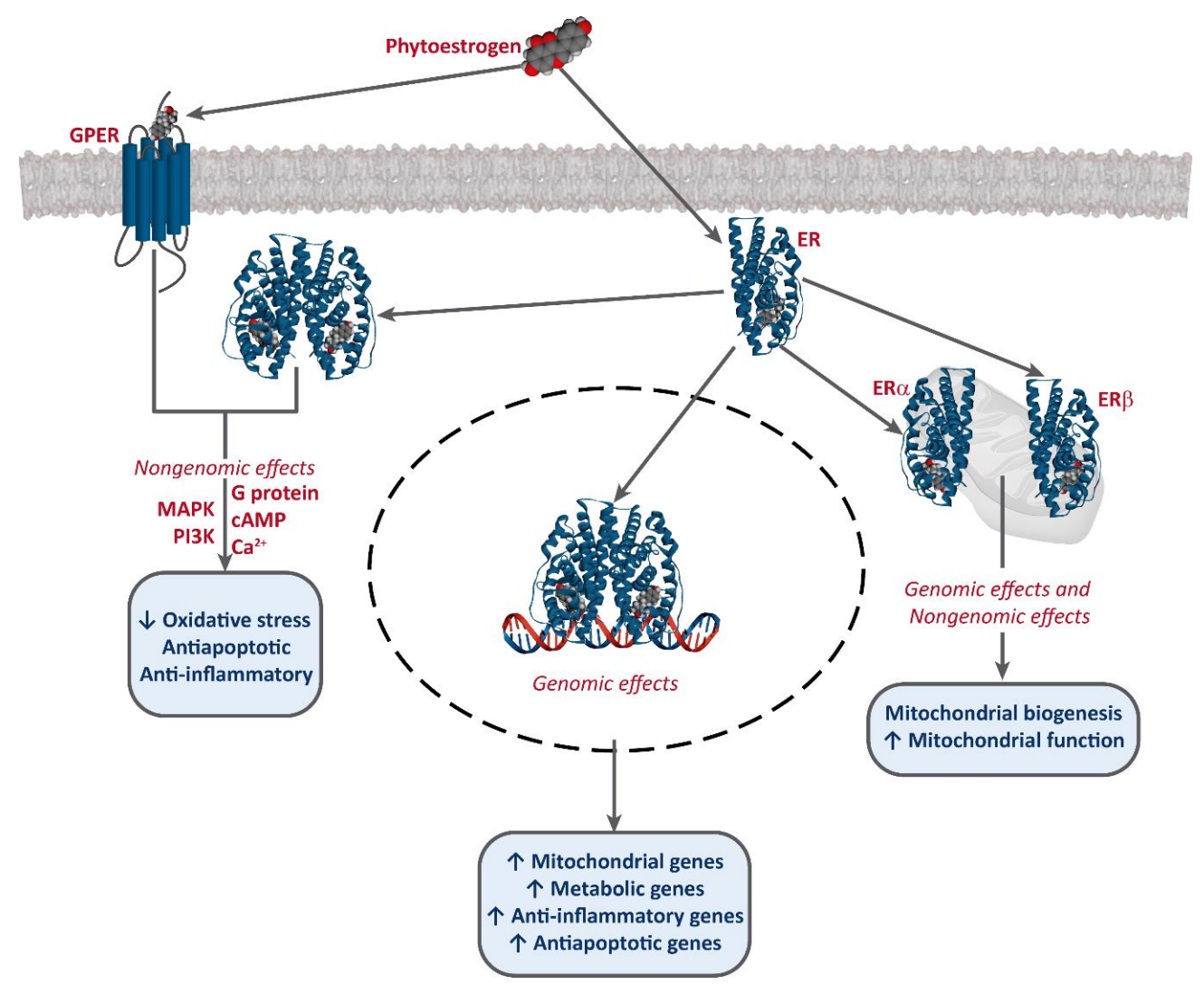

Figure 2. Interaction of phytoestrogens with ERs and GPER and their described effects.

Phytoestrogens also have ER-independent effects. For instance, genistein and resveratrol can act as tyrosine kinase inhibitors, altering the activity of some downstream kinases [55]. Moreover, some studies also report an epigenetic mechanism for some phytoestrogens and the involvement of miRNA expression [56-58], and the modulation of chromatin structure [53,59]. However, they are mostly known as potent antioxidants, protecting cellular structures from ROS, such as epicatechin [25] or lignans [35], although the in vivo effects of these are much greater, due to the conversion into their active metabolites, enterolactone and enterodiol [60]. Furthermore, some studies report that at high concentrations, phytoestrogens may have an oxidant effect and induce cell death. This effect has been described for several compounds, including genistein [61-64], resveratrol [65,66], and xanthohumol [67-69]. Resveratrol is one of the most studied phytoestrogens, and several clinical trials have been developed to test its potential as a anti-cancer treatment $[44,47,70]$, and some analogs are being designed [42,43].

These mechanisms of action have been associated with the chemoprevention potential of phytoestrogens. For instance, in Asian populations, soy consumption correlates with a lower incidence of prostate and breast cancer, which has been attributed to the presence of genistein in soy [71]. 
Genistein has a higher affinity for $\operatorname{ER} \beta(87 \%)$ than for $\operatorname{ER} \alpha(4 \%)$, and $E R \beta$ has been reported to have a protective effect against malignant transformation. In this regard, the chemoprevention effect of genistein may depend on the $\mathrm{ER} \alpha / \mathrm{ER} \beta$ ratio [15,72-74].

Other phytoestrogens have been less widely studied, although they also show potential as chemopreventive agents. Quercetin may reduce the incidence of esophageal and stomach cancers, although this protection has not been observed for lung cancer [14,75-77]. There is also evidence for mild protection against gastrointestinal cancers associated with the consumption of tea flavanols [78]. Also, most epidemiological studies about lignans suggest that their intake reduces the risk of premenopausal breast cancer and possibly of postmenopausal breast cancer [39].

\section{Phytoestrogens as Cancer Treatment}

\subsection{Phytoestrogens and Hormonal Therapy}

The development and growth of some types of cancer are influenced by endocrine hormones, such as estrogens, progesterone, or androgens. Hormonal therapy is the main choice of treatment for these hormone-dependent cancers, which are breast, prostate, and uterine cancers [79]. This treatment consists of a specific modulator of the hormone receptor, which blocks its downstream signaling pathway. Tamoxifen (TAM) is one of the most commonly used drugs in hormonal therapy.

Controversial results are described for the combination of hormonotherapy with phytoestrogens. These different results could be explained, in part, because phytoestrogens may produce different effects in cancer cells depending on their $\operatorname{Er} \alpha / E R \beta$ ratio and the different affinity for these two receptors. Our group has reported that combining genistein and TAM increases the anti-tumor activity of this treatment in T47D cells (low ER $\alpha / E R \beta$ ratio), while this combination decreases ROS production in MCF-7 cells (higher ER $\alpha / E R \beta$ ratio) and increases cell viability [72]. Moreover, genistein seems to have an antagonizing effect on aromatase inhibitors for breast cancer at physiological concentration [80]. Constantinou et al. [81] reported that a diet combining daidzein and TAM results in increased protection from breast carcinogenesis in rats, although the combination with genistein antagonizes this chemopreventive effect. Tonetti et al. [82] also reported that genistein and daidzein antagonize TAM in vitro. On the other hand, a later study analyzing combining equol, a daidzein metabolite, and 4-hydroxy-tamoxifen, the bioactive metabolite of TAM, concluded that this strategy increases apoptosis and TAM efficacy in MCF-7 breast cancer cells [83]. The treatment with apigenin also shows the potential to overcome TAM resistance in SKOV3 ovarian cancer cells [84]. Interestingly, Zhang et al. [85] recently reported that rats that receive the combination treatment of TAM and genistein do not show any improvements; however, if the consumption of genistein starts at prepubertal or adult age, it shows a beneficial effect.

\subsection{Phytoestrogens and Chemotherapy}

Chemotherapy can be classified depending on the mechanism of action of each drug. This includes alkylating agents, anti-metabolites, topoisomerase inhibitors, mitotic inhibitors, and targeted therapies, among others. The development of resistance to these drugs is the main limitation of chemotherapy. The combination of chemotherapeutic agents with phytoestrogens has been studied to overcome resistance to treatment. There are controversial results, and very few clinical studies have been fully developed to this date, since most of them have been canceled, due to their lack of effectiveness.

Alkylating agents include platin-based therapies, such as cisplatin and oxaliplatin, and other drugs, such as dacarbazine. These agents form adducts in DNA and interfere with DNA repair mechanisms, eventually stopping cells from dividing. They are used to treat blood cancers, sarcomas, and lung, bladder, breast, and ovarian cancers [86]. The effects of combining phytoestrogens and alkylating agents seem to be dependent on the type of cancer. Genistein may help to overcome resistance to cisplatin in gastric cancer [87] and could contribute to reducing the dose of cisplatin used for BxPC-3 pancreatic cancer cell line by blocking the cisplatin-induced activation of NF- $\mathrm{kB}$ [88]. However, 
other studies report that genistein and daidzein show an antagonizing effect in combination with cisplatin in medulloblastoma, breast, and colon cancer cells $[89,90]$.

Other phytoestrogens also show the potential to increase the efficacy of alkylating agents in several studies. The combination of cisplatin with apigenin seems to inhibit cell proliferation in breast cancer cell lines and decreases telomerase activity, limiting one of the mechanisms to escape apoptosis and induce metastasis [91]. Another study found that apigenin increases the efficacy of cisplatin in B16-BL6 melanoma cells in vivo, significantly reducing tumor volume in mice [92]. Resveratrol, in combination with cisplatin in SW620 and HT-29 colon cancer cells, results in lower cell viability compared to the treatment alone [93], while the combination with oxaliplatin increased its anti-tumor activity in SW480 and SW620 cells [94]. Quercetin also improves the response of lung cancer cells to cisplatin, although this effect was not attributed to an increase in antioxidant enzymes [95]. On the other hand, Sharma et al. [96] reported that this combination increased oxidative stress and cytotoxicity in HeP2 laryngeal carcinoma cells. On the contrary, for ovarian cancer, only the combination of cisplatin and kaempferol had success in overcoming cisplatin resistance in OVCAR-3 cells, while apigenin, genistein, and quercetin showed no improvement [97]. EGCG may also potentiate the anti-tumor activity of cisplatin in ovarian cancer cells [98].

Some phytoestrogens do not have any influence on the activity of cisplatin, but show other beneficial effects. For instance, cotreatment of formononetin and cisplatin inhibits apoptosis in kidney epithelial cells by suppressing ROS production, suggesting a protective effect against secondary effects [99]. Furthermore, treatment with biochanin A before cisplatin treatment triggers the activation of the Nrf2 pathway, resulting in a protective effect against nephrotoxicity, which is a common complication of cisplatin treatment [100].

Mitotic inhibitors usually act by binding to tubulin or by inducing microtubule disassembly, preventing mitosis. These drugs include docetaxel, paclitaxel, or vincristine, and are used to treat breast, lung, and blood cancers [86]. In B-cell tumors, the cotreatment of resveratrol and paclitaxel in vitro synergistically increases apoptosis, suggesting a sensitizing effect that could reduce the dose of paclitaxel [101]. Öztürk et al. [102] also showed this synergistic effect in glioblastoma cancer cells, which increased ROS production and induced apoptosis. EGCG also increases the efficacy of docetaxel and paclitaxel in prostate cancer cells [103] and the activity of paclitaxel in breast cancer cells and in vivo [104]. Another study showed that isoxanthohumol may also be a potential coadjuvant for melanoma, as it improves the anti-cancer activity of paclitaxel both in vivo and in vitro [105]. A pretreatment of genistein for $24 \mathrm{~h}$ also shows a sensitizing effect on docetaxel in BxPC-3 pancreatic cancer cell line, inhibiting NF- $\mathrm{KB}$ signaling, and triggering apoptosis [88].

Anti-metabolites are commonly used drugs to treat leukemias and solid tumors, such as breast, ovarian, and intestinal tract cancers. The most used are 5-fluorouracil (5-FU) and gemcitabine, and they interfere with DNA and RNA synthesis, as they substitute the usual metabolites [86]. Several reports have studied resveratrol in combination with 5-FU. Our group has previously reported that treatment with resveratrol in combination with 5-FU increases oxidative stress in colon cancer cells and shows higher cytotoxicity compared to the 5-FU alone $[65,93]$. Moreover, combining resveratrol with 5-FU is also effective in a model on murine liver cancer, allowing a reduction of the administered dose of 5-FU [106], and in B16 melanoma cells in vitro and in vivo [107]. Resveratrol can also sensitize pancreatic cancer cells to gemcitabine in vitro and in vivo [108]. Frampton et al. [109] also reported that resveratrol increases the anti-tumor effect of both 5-FU and gemcitabine in cholangiocarcinoma cell lines.

Genistein has been shown to increase the cytotoxic effect of gemcitabine in different cancer types, presumably overcoming chemoresistance by suppressing the Akt/NF- $\mathrm{kB}$ pathway induced by chemotherapy, as shown in osteosarcoma cells [110], ovarian cancer cells [111], and in a mouse model of pancreatic cancer [112]. Genistein has also shown the potential to synergize with 5-FU in pancreatic cancer cells and in in vivo models [113]. Finally, Tang et al. [114] reported that EGCG also increases the activity of gemcitabine in pancreatic cancer cells. 
Topoisomerases are the enzymes responsible for the uncoiling of DNA during DNA replication. Irinotecan, topotecan, and etoposide are the most used topoisomerase inhibitors in clinical practice to treat lung, ovarian and gastrointestinal cancers, as well as some leukemias [86]. Several studies have reported an improvement of the cytotoxic activity of these drugs in combination with phytoestrogens. For instance, a combination of etoposide and resveratrol results in lower cell viability in SW620 and HT-29 colon cancer cells compared to the chemotherapy treatment alone [93]. Guo et al. [115] recently showed that the combination of daidzein with topotecan results in lower cell viability both in vitro and in vivo, as well as a reversal of resistance to chemotherapy.

Anti-tumor antibiotics act by interfering with the enzymes involved in DNA replication or causing strand breakage. The most common include daunomycin, doxorubicin, and epirubicin. These drugs are commonly used to treat soft tissue sarcomas and hematological cancers, as well as some types of carcinoma, although a major setback of these drugs is their cardiotoxicity [86]. Doxorubicin is probably the most studied drug in combination with phytoestrogens, and contradictory results have been obtained. Rigalli et al. [116] showed that treatment of genistein in MCF-7 and MDA-MB-231 breast cancer cell lines increases their chemoresistance to doxorubicin. Another study showed that this combination does not improve the cytotoxic activity of doxorubicin in MCF-7 cells [117]. However, Xue et al. [118] reported that genistein-treated cells overcome their resistance to doxorubicin.

The combination of EGCG with doxorubicin produces synergistic effects inhibiting metastasis and cell proliferation in prostate cancer cells and in vivo [119]. Reedijk et al. [120] also showed that catechins may increase the anti-tumor activity of doxorubicin in hepatocarcinoma cell lines and in a mice model. Du et al. [121] showed that luteolin increases the efficacy of doxorubicin and decreases its secondary effects by increasing the antioxidant capacity of serum, while Staedler et al. [122] reported the same results with the combination of doxorubicin and quercetin. The combination of kaempferol with doxorubicin increases ROS production and cell death, increasing the efficacy of the drug in glioblastoma cells [123]. In acute myeloid leukemia cells resistant to doxorubicin, treatment with resveratrol for $24 \mathrm{~h}$ seems to overcome drug resistance and increase apoptosis [124]. Resveratrol has also been described to protect from doxorubicin-induced cardiotoxicity [45]. Formononetin also increases the sensitivity to doxorubicin in some glioma cell lines, although in this case, the antioxidant activity was not tested [125]. The combination of doxorubicin with biochanin A also results in a synergistic effect inhibiting cell proliferation of osteosarcoma cells [126].

Dash and Konkimalla [127] recently reported that the encapsulation in liposomes of biochanin A and doxorubicin increases the uptake of chemotherapy in COLO205 doxorubicin-resistant colon cancer cells and increases their sensitivity to the drug. The encapsulation of genistein and doxorubicin also shows potential for metastatic prostate cancer [128].

Exposure of Caco-2 cells to 8-hydroxydaidzein, a daidzein derivative that is produced in the liver, increases ROS levels and the sensitivity of these cells to epirubicin, as evidenced by the p53-induced cell cycle arrest and triggering of apoptosis [129]. Somjen et al. [130] performed an in vivo study where they conjugated another derivative of daidzein with daunomycin, improving the efficiency of the drug in ovarian cancer, and showed less secondary effects, such as weight loss in mice. Trichostatin A (TSA) is also an antibiotic used as chemotherapy for prostate, breast, and gastrointestinal cancer. This compound can inhibit histone deacetylases in mammalian cells. The combination of TSA with genistein significantly reduces the viability of Hep-2 laryngeal cancer cells [131] and A549 lung cancer cells [132].

Finally, targeted therapies include small molecules and antibodies that target some proteins or block signaling pathways in cancer cells. The most studied include sunitinib, bortezomib, and sorafenib [133]. Genistein seems to contribute to enhancing the effect of sorafenib in hepatocellular carcinoma in vivo [134]. On the contrary, Rigalli et al. [135] reported that genistein, at concentrations of 1 and $10 \mu \mathrm{M}$, induces a higher resistance of HepG2 hepatocellular carcinoma cells to sorafenib.

Resveratrol is also a promising adjuvant for this type of therapy. Ivanova et al. [136] recently showed that combining resveratrol with some targeted drugs, such as barasertib, synergistically increases 
ROS production and apoptosis in leukemic cells, while leaving normal lymphocytes unaltered. Moreover, resveratrol also improves the efficacy of sorafenib in MCF-7 breast cancer cells by increasing ROS production and apoptosis [137]. The combination of sorafenib and biochanin A in some hepatocarcinoma cell lines also results in synergistic effects increasing cell death [138], and formononetin has been reported to increase the cytotoxic effect of sunitinib in vivo [139]. Finally, navitoclax (ABT-263) is an experimental drug currently in evaluation for solid tumors and non-Hodgkin's lymphoma. The combination of Navitoclax and apigenin synergistically enhanced the effect of this drug in several colon cancer cell lines and suppressed tumor growth by $70 \%$ in xenograft mice, without observing a worsening of secondary effects [140].

Some anti-cancer compounds can be classified into prodrugs. These molecules have little or no effect until they are metabolized and converted into their active form. This strategy is often used to overcome problems with drug bioavailability, and more recently, with tissue-selective distribution [141,142]. Phytoestrogens themselves have been considered as prodrugs. Some examples are lignans, which, as mentioned before, are metabolized into their active compounds by gut bacteria; daidzein and formononetin, metabolized into equol also by intestinal bacteria; apigenin and kaempferol, converted into luteolin and quercetin [143,144], respectively, and activation of chalcones by the action of the cytochrome P450 enzyme [145]. Several strategies to develop prodrugs of phytoestrogens are currently under study and are reviewed elsewhere [146,147]. Furthermore, some studies have analyzed the combination of phytoestrogens with other prodrugs. For instance, the combination of genistein and a prodrug of vitamin D synergistically decreases the proliferation of prostate and breast cancer cells in vitro [148]. Daidzein has also been used in combination with a prodrug based on allicin, to specifically target ovarian cancer cells in an animal model [149]. Di et al. [150] showed that a combination of a specific antibody targeting prostate cancer cells, glucuronidase, and enterolactone glucuronide could decrease the dose of docetaxel used. Finally, another study developed a new potential prodrug based on benzimidazole combined with chalcones with comparable or higher effectivity than cisplatin in breast and ovarian cancer cells in vitro [151].

Even though the combination of phytoestrogens and chemotherapy shows some promising effects in vitro and in some in vivo models, the clinical studies that have been carried out reported little significant improvements. For instance, a phase II study testing the addition of genistein to gemcitabine and erlotinib treatments for pancreatic cancer patients reported no improvement in the anti-tumor activity of these drugs, although the combination was well tolerated [152]. Another phase I clinical study showed that the combination of a derivative of genistein and gemcitabine may be beneficial for some specific pancreatic cancer patients [153]. This may open the door to the development of drugs based on the structure of phytoestrogens with some modifications to make them potential coadjuvant treatments.

\subsection{Phytoestrogens and Radiotherapy}

Ionizing $\gamma$-radiation is the major choice for radiotherapy, although it has adverse effects, such as immunosuppression, inflammation, epigenetic modulation, necrosis, and secondary carcinogenesis induction, among others. These secondary effects are mainly due to the induction of ROS production, which leads to cellular oxidative damage [154]. Since phytoestrogens have antioxidant properties, they have been studied as radioprotective compounds for non-tumor cells. However, other studies support that high doses of some phytoestrogens may act as pro-oxidant molecules, thus increasing the sensitivity of cancer cells to radiotherapy. The most studied phytoestrogens as radiosensitizers and radioprotectors are genistein and resveratrol, although there are reports on the effect of other compounds.

In HL-60 leukemia cells, treatment with genistein induces cell cycle arrest and ROS production, which renders cells more sensitive to $\gamma$-radiation. At the same time, genistein has a protective effect against radiation on normal lymphocytes [155]. This radiosensitizing effect was also reported for prostate cancer cells and in in vivo experiments [156]. Genistein and daidzein also show potential as radiosensitizers in PC-3 prostate cancer cells in vitro and in vivo [157]. Resveratrol has been 
described to improve sensitivity in melanoma cells [158], prostate cancer cells [159], and cervical cancer cells $[160,161]$. Finally, naringin, a glycone form of naringenin usually found in citrus fruits, has shown potential as a radioprotector in mice, particularly in the spleen, one of the most sensitive organs to radiation. A pretreatment with naringin may protect cells from radiation-induced oxidative damage by increasing the expression and activity of antioxidant enzymes and suppressing the activation of NF-kB, thus attenuating the adverse effects of radiotherapy [162].

Table 1 summarizes all the positive, neutral, and negative effects described for the combination of phytoestrogens and different choices of anti-cancer treatment.

Table 1. Summary of the described effects of phytoestrogens in combination with anti-cancer therapies.

\begin{tabular}{|c|c|c|c|c|}
\hline Phytoestrogen & Treatment Combination & Cancer Type & Effect & Reference \\
\hline \multirow{3}{*}{ Apigenin } & Tamoxifen & Ovarian Cancer & + & [84] \\
\hline & Ciaplatin & $\begin{array}{c}\text { Breast and Ovarian Cancer, } \\
\text { Melanoma }\end{array}$ & $+/$ N.E. & {$[91,92,97]$} \\
\hline & Navitoclax & Colon Cancer & + & [140] \\
\hline \multirow{3}{*}{ Biochanin A } & Doxorubicin & Osteosarcoma, Colon Cancer & + & {$[126,127]$} \\
\hline & Sorafenib & Hepatocarcinoma & + & {$[138]$} \\
\hline & Cisplatin & Kidney Cells & S.E. improvement & {$[99,100]$} \\
\hline Catechins & Doxorubicin & Hepatocarcinoma & + & {$[120]$} \\
\hline \multirow{6}{*}{ Daidzein } & TAM & Breast Cancer & - & [82] \\
\hline & Cisplatin & $\begin{array}{l}\text { Medulloblastoma, Breast, } \\
\text { and Colon Cancer }\end{array}$ & - & {$[89,90]$} \\
\hline & Topotecan & Breast Cancer & + & [115] \\
\hline & Epirubicin & Colon Cancer & + & [129] \\
\hline & Daunomycin & Ovarian Cancer & + , S.E. improvement & [130] \\
\hline & Radio & Prostate Cancer & + & [157] \\
\hline \multirow{4}{*}{ EGCG } & Oxaliplatin & Ovarian Cancer & + & [98] \\
\hline & Docetaxel, paclitaxel & Prostate and Breast Cancer & + & {$[103,104]$} \\
\hline & Gemcitabine & Pancreatic Cancer & + & [114] \\
\hline & Doxorubicin & Prostate Cancer & + & [119] \\
\hline Equol & TAM & Breast Cancer & + & [83] \\
\hline \multirow{3}{*}{ Formononetin } & Sunitibib & Breast Cancer & + & [139] \\
\hline & Doxorubicin & Glioma & + & [125] \\
\hline & Cisplatin & Kidney Cells & S.E. improvement & {$[99,100]$} \\
\hline \multirow{13}{*}{ Genistein } & Tamoxifen & Breast Cancer & $+/-$ & [72] \\
\hline & $\begin{array}{l}\text { Fadrozole (Aromatase } \\
\text { Inhibitor) }\end{array}$ & Breast Cancer & - & [80] \\
\hline & Tamoxifen & Breast Cancer & $+/-$ & {$[81,82]$} \\
\hline & Cisplatin & Gastric and pancreatic Cancer & + & {$[87,88]$} \\
\hline & Docetaxel & Pancreatic Cancer & + & {$[88]$} \\
\hline & Cisplatin & $\begin{array}{l}\text { Medulloblastoma, Breast, } \\
\text { Ovarian, and Colon Cancer }\end{array}$ & -/N.E. & {$[89,90,97]$} \\
\hline & Gemcitabine & $\begin{array}{l}\text { Osteosarcoma, Ovarian and } \\
\text { Pancreatic Cancer }\end{array}$ & + & [110-112] \\
\hline & 5-FU & Pancreatic Cancer & + & [113] \\
\hline & Doxorubicin & Breast Cancer & -/+/N.E. & [116-118] \\
\hline & Doxorubicin & Prostate Cancer & + & [128] \\
\hline & TSA & $\begin{array}{l}\text { Lung and Laryngeal } \\
\text { Carcinoma }\end{array}$ & + & {$[131,132]$} \\
\hline & Sorafenib & Hepatocarcinoma & $+/-$ & {$[134,135]$} \\
\hline & Radio & Leukemia and Prostate Cancer & + , S.E. improvement & [155-157] \\
\hline
\end{tabular}


Table 1. Cont.

\begin{tabular}{|c|c|c|c|c|}
\hline Phytoestrogen & Treatment Combination & Cancer Type & Effect & Reference \\
\hline Isoxanthohumol & Paclitaxel & Melanoma & + & [105] \\
\hline Kaempferol & Cisplatin & Ovarian Cancer & + & [97] \\
\hline Kaempferol & Doxorubicin & Glioblastoma & + & [123] \\
\hline Luteolin & Doxorubicin & Breast Cancer & + & [121] \\
\hline Naringin & Radiotherapy & Splenocytes & S.E. improvement & [162] \\
\hline \multirow{2}{*}{ Quercetin } & Doxorubicin & Breast Cancer & + & [122] \\
\hline & Cisplatin & $\begin{array}{l}\text { Ovarian Cancer, Lung, } \\
\text { and Laryngeal Carcinoma }\end{array}$ & + & [95-97] \\
\hline \multirow{10}{*}{ Resveratrol } & Cisplatin & Colon Cancer & + & [93] \\
\hline & Etoposide & Colon Cancer & + & [93] \\
\hline & Oxaliplatin & Colon Cancer & + & [94] \\
\hline & $5 \mathrm{FU}$ & $\begin{array}{c}\text { Colon and Liver Cancer, } \\
\text { Melanoma, } \\
\text { and Cholangiocarcinoma }\end{array}$ & + & {$[65,93,106,107,109]$} \\
\hline & Paclitaxel & $\begin{array}{l}\text { B-cell Malignancies, } \\
\text { Glioblastoma }\end{array}$ & + & {$[101,102]$} \\
\hline & Gemcitabine & $\begin{array}{l}\text { Pancreatic Cancer and } \\
\text { Cholangiocarcinoma }\end{array}$ & + & {$[108,109]$} \\
\hline & Doxorubicin & Acute Myeloid Leukemia & + , S.E. improvement & {$[45,124]$} \\
\hline & Barasertib & Leukemia & + & [136] \\
\hline & Sorafenib & Breast Cancer & + & [137] \\
\hline & Radiotherapy & $\begin{array}{l}\text { Melanoma, Prostate, } \\
\text { and Cervical Cancer }\end{array}$ & + & [158-161] \\
\hline
\end{tabular}

Phytoestrogens are ordered alphabetically. + indicates an increase in efficacy of the anti-cancer treatment; - indicates interference with the anti-cancer treatments; N.E., no effects; S.E. improvement, side effects improvement.

\section{Conclusions}

Phytoestrogen consumption has been associated with a reduction in cancer incidence, and they are studied as promising chemopreventive compounds. Apart from interfering with the normal signaling pathways of estrogens and modulate gene expression, phytoestrogens are also potent antioxidants, modulate normal protein activity, and regulate epigenetics (Figure 3). This way, phytoestrogens have the potential to limit cell proliferation in different types of tumors.

Furthermore, phytoestrogens may sensitize cancer cells to anti-cancer treatments, including hormonotherapy, chemotherapy, and radiotherapy. Some reports also show that phytoestrogens could also protect normal cells from the secondary effects without affecting the efficacy of treatment. However, further research and clinical studies must be carried out to evaluate the true potential of phytoestrogens as an option for cancer therapy, establish the optimal concentration and which patients could benefit from it, and ensure their safety. Until now, most clinical studies regarding phytoestrogens and cancer have been canceled, due to a lack of effect. In this regard, several investigations are focused on designing analogs or strategies, such as encapsulation, to improve the efficacy of phytoestrogen as treatments or coadjuvants for some types of cancer. 


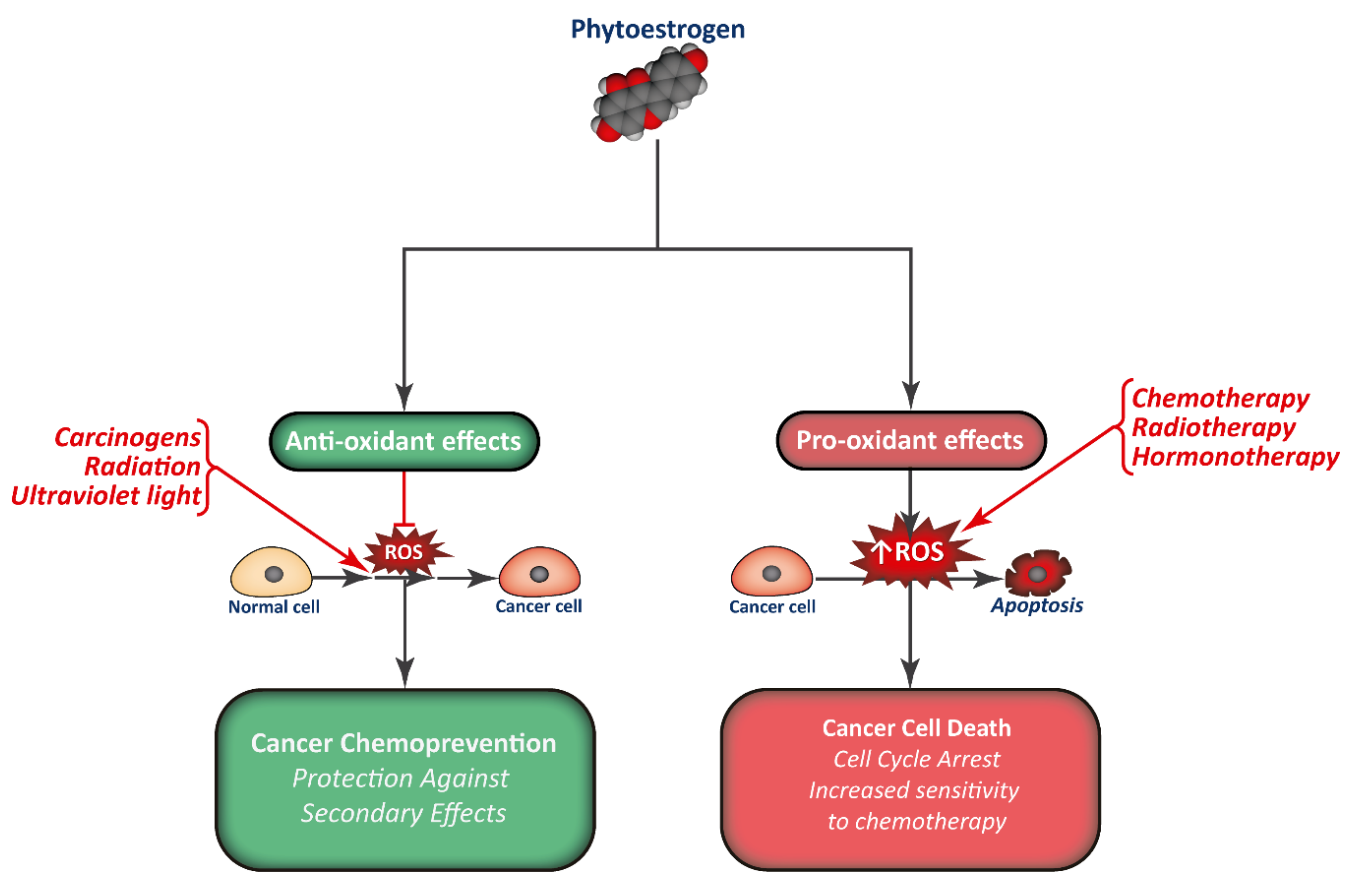

Figure 3. Combination of phytoestrogens with anti-cancer treatments may render cancer cells more sensitive to treatment, in part by increasing ROS production, while normal cells may be protected from the secondary effects of therapy.

Author Contributions: All authors contributed equally to this work. All authors have read and agreed to the published version of the manuscript.

Funding: This research received no external funding.

Conflicts of Interest: The authors declare no conflict of interest.

\section{References}

1. Roca, P.; Sastre-Serra, J.; Nadal-Serrano, M.; Pons, D.G.; Blanquer-Rossello, M.D.; Oliver, J. Phytoestrogens and Mitochondrial Biogenesis in Breast Cancer. Influence of Estrogen Receptors Ratio. Curr. Pharm. Des. 2014, 20, 5594-5618. [CrossRef]

2. Senthilkumar, H.A.; Fata, J.E.; Kennelly, E. Phytoestrogens: The current state of research emphasizing breast pathophysiology. Phytotherapy Res. 2018, 32, 1707-1719. [CrossRef] [PubMed]

3. Qu, X.; Fang, Y.; Zhang, M.; Zhang, Y. Phytoestrogen Intake and Risk of Ovarian Cancer: A Meta-Analysis of 10 Observational Studies. Asian Pac. J. Cancer Prev. 2014, 15, 9085-9091. [CrossRef] [PubMed]

4. Sonn, G.A.; Aronson, W.; Litwin, M.S. Impact of diet on prostate cancer: A review. Prostate Cancer Prostatic Dis. 2005, 8, 304-310. [CrossRef] [PubMed]

5. Shimazu, T.; Inoue, M.; Sasazuki, S.; Iwasaki, M.; Sawada, N.; Yamaji, T.; Tsugane, S. Plasma isoflavones and the risk of lung cancer in women: A nested case-control study in Japan. Cancer Epidemiol. Biomark. Prev. 2011, 20, 419-427. [CrossRef]

6. Wu, Y.; Zhang, L.; Na, R.; Xu, J.; Xiong, Z.; Zhang, N.; Dai, W.; Jiang, H.-W.; Ding, Q. Plasma genistein and risk of prostate cancer in Chinese population. Int. Urol. Nephrol. 2015, 47, 965-970. [CrossRef]

7. Ko, K.-P.; Yeo, Y.; Yoon, J.-H.; Kim, C.-S.; Tokudome, S.; Ngoan, L.T.; Koriyama, C.; Lim, Y.-K.; Chang, S.-H.; Shin, H.-R.; et al. Plasma phytoestrogens concentration and risk of colorectal cancer in two different Asian populations. Clin. Nutr. 2018, 37, 1675-1682. [CrossRef]

8. Iwasaki, M.; Tsugane, S. Risk factors for breast cancer: Epidemiological evidence from Japanese studies. Cancer Sci. 2011, 102, 1607-1614. [CrossRef]

9. Nikolic, I.; Savić-Gajić, I.; Tačić, A.; Savić, I. Classification and biological activity of phytoestrogens: A review. Adv. Technol. 2017, 6, 96-106. [CrossRef] 
10. Cos, P.; De Bruyne, T.; Apers, S.; Berghe, D.V.; Pieters, L.; Vlietinck, A.J. Phytoestrogens: Recent Developments. Planta Med. 2003, 69, 589-599.

11. Wang, T.-Y.; Li, Q.; Bi, K. Bioactive flavonoids in medicinal plants: Structure, activity and biological fate. Asian J. Pharm. Sci. 2018, 13, 12-23. [CrossRef] [PubMed]

12. Panche, A.N.; Diwan, A.D.; Chandra, S.R. Flavonoids: An overview. J. Nutr. Sci. 2016, 5, e47. [CrossRef] [PubMed]

13. Farnsworth, N.R.; Bingel, A.S.; Cordell, G.A.; Crane, F.A.; Fong, H.H.S. Potential Value of Plants as Sources of New Antifertility Agents II. J. Pharm. Sci. 1975, 64, 717-754. [CrossRef]

14. Graf, B.A.; Milbury, P.E.; Blumberg, J.B. Flavonols, Flavones, Flavanones, and Human Health: Epidemiological Evidence. J. Med. Food 2005, 8, 281-290. [CrossRef] [PubMed]

15. Spagnuolo, C.; Russo, G.L.; Orhan, I.E.; Habtemariam, S.; Daglia, M.; Sureda, A.; Nabavi, S.M.; Devi, K.P.; Loizzo, M.R.; Tundis, R. Genistein and Cancer: Current Status, Challenges, and Future Directions. Adv. Nutr. 2015, 6, 408-419. [CrossRef] [PubMed]

16. Chan, K.K.L.; Siu, M.K.Y.; Jiang, Y.-X.; Wang, J.-J.; Leung, T.H.Y.; Ngan, H.Y.S. Estrogen receptor modulators genistein, daidzein and ERB-041 inhibit cell migration, invasion, proliferation and sphere formation via modulation of FAK and PI3K/AKT signaling in ovarian cancer. Cancer Cell Int. 2018, 18, 65. [CrossRef]

17. Kuiper, G.G.J.M.; Carlsson, B.; Grandien, K.; Enmark, E.; Häggblad, J.; Nilsson, S.; Gustafsson, J.-A. Comparison of the Ligand Binding Specificity and Transcript Tissue Distribution of Estrogen Receptors $\alpha$ and $\beta$. Endocrinology 1997, 138, 863-870. [CrossRef]

18. Konar, N. Non-isoflavone phytoestrogenic compound contents of various legumes. Eur. Food Res. Technol. 2013, 236, 523-530. [CrossRef]

19. Blomquist, C.H.; Lima, P.H.; Hotchkiss, J.R. Inhibition of $3 \alpha$-hydroxysteroid dehydrogenase (3 $\alpha$-HSD) activity of human lung microsomes by genistein, daidzein, coumestrol and C18-, C19- and C21-hydroxysteroids and ketosteroids. Steroids 2005, 70, 507-514. [CrossRef]

20. Amin, A.; Buratovich, M. The Anti-Cancer Charm of Flavonoids: A Cup-of-Tea Will Do You Good! Front. Anti-Cancer Drug Discov. 2007, 2, 109-117. [CrossRef]

21. Jiang, N.; Doseff, A.I.; Grotewold, E. Flavones: From Biosynthesis to Health Benefits. Plants 2016, 5, 27. [CrossRef] [PubMed]

22. Hostetler, G.L.; A Ralston, R.; Schwartz, S.J. Flavones: Food Sources, Bioavailability, Metabolism, and Bioactivity. Adv. Nutr. 2017, 8, 423-435. [CrossRef] [PubMed]

23. Cos, P.; Ying, L.; Calomme, M.; Hu, J.P.; Cimanga, K.; Van Poel, B.; Pieters, L.; Vlietinck, A.A.J.; Berghe, D.V. Structure-Activity Relationship and Classification of Flavonoids as Inhibitors of Xanthine Oxidase and Superoxide Scavengers. J. Nat. Prod. 1998, 61, 71-76. [CrossRef] [PubMed]

24. Onzalez-Mejia, M.E.; Voss, O.H.; Murnan, E.J.; Doseff, A.I. Apigenin-induced apoptosis of leukemia cells is mediated by a bimodal and differentially regulated residue-specific phosphorylation of heat-shock protein-27. Cell Death Dis. 2010, 1, e64. [CrossRef]

25. Shay, J.; Elbaz, H.A.; Lee, I.; Zielske, S.P.; Malek, M.H.; Hüttemann, M. Molecular Mechanisms and Therapeutic Effects of (-)-Epicatechin and Other Polyphenols in Cancer, Inflammation, Diabetes, and Neurodegeneration. Oxidative Med. Cell. Longev. 2015, 2015, 1-13. [CrossRef]

26. Yang, C.S.; Wang, H. Cancer Preventive Activities of Tea Catechins. Molecules 2016, 21, 1679. [CrossRef]

27. Salehi, B.; Fokou, P.V.T.; Sharifi-Rad, M.; Zucca, P.; Pezzani, R.; Martins, N.; Sharifi-Rad, J. The Therapeutic Potential of Naringenin: A Review of Clinical Trials. Pharmaceuticals 2019, 12, 11. [CrossRef]

28. Štulíková, K.; Karabín, M.; Nešpor, J.; Dostálek, P. Therapeutic Perspectives of 8-Prenylnaringenin, a Potent Phytoestrogen from Hops. Molecules 2018, 23, 660. [CrossRef]

29. Milligan, S.; Kalita, J.; Pocock, V.; Heyerick, A.; De Cooman, L.; Rong, H.; De Keukeleire, D. Oestrogenic activity of the hop phyto-oestrogen, 8-prenylnaringenin. Reproduction 2002, 123, 235-242. [CrossRef]

30. Monteiro, R.; Becker, H.; Azevedo, I.; Calhau, C. Effect of Hop (Humulus lupulus L.) Flavonoids on Aromatase (Estrogen Synthase) Activity. J. Agric. Food Chem. 2006, 54, 2938-2943. [CrossRef]

31. Zhuang, C.; Zhang, W.; Sheng, C.; Zhang, W.; Xing, C.; Miao, Z. Chalcone: A Privileged Structure in Medicinal Chemistry. Chem. Rev. 2017, 117, 7762-7810. [CrossRef] [PubMed]

32. Wang, L.-S.; Stoner, G.D. Anthocyanins and their role in cancer prevention. Cancer Lett. 2008, 269, $281-290$. [CrossRef] [PubMed] 
33. Martín, J.; Navas, M.J.; Jiménez-Moreno, A.M.; Asuero, A.G. Anthocyanin Pigments: Importance, Sample Preparation and Extraction. In Phenolic Compounds-Natural Sources, Importance and Applications; IntechOpen: London, UK, 2017.

34. Durazzo, A.; Lucarini, M.; Camilli, E.; Marconi, S.; Gabrielli, P.; Lisciani, S.; Gambelli, L.; Aguzzi, A.; Novellino, E.; Santini, A.; et al. Dietary Lignans: Definition, Description and Research Trends in Databases Development. Molecules 2018, 23, 3251. [CrossRef] [PubMed]

35. Satake, H.; Koyama, T.; Bahabadi, S.E.; Matsumoto, E.; Ono, E.; Murata, J. Essences in Metabolic Engineering of Lignan Biosynthesis. Metabolites 2015, 5, 270-290. [CrossRef] [PubMed]

36. Tsao, R. Chemistry and Biochemistry of Dietary Polyphenols. Nutrients 2010, 2, 1231-1246. [CrossRef] [PubMed]

37. Manach, C.; Scalbert, A.; Morand, C.; Rémésy, C.; Jiménez, L. Polyphenols: Food sources and bioavailability. Am. J. Clin. Nutr. 2004, 79, 727-747. [CrossRef]

38. De la Rosa, L.A.; Alvarez-Parrilla, E.; González-Aguilar, G.A. Fruit and Vegetable Phytochemicals: Chemistry, Nutritional Value, and Stability; Wiley-Blackwell: Hoboken, NJ, USA, 2010.

39. Cotterchio, M.; Boucher, B.; Kreiger, N.; Mills, C.A.; Thompson, L.U. Dietary phytoestrogen intake-Lignans and isoflavones-And breast cancer risk (Canada). Cancer Causes Control 2007, 19, 259-272. [CrossRef]

40. Andersen, Ø.M.; Markham, K.R. Flavonoids: Chemistry, Biochemistry, and Applications; CRC, Taylor \& Francis: Abingdon, UK, 2006.

41. Peirotén, Á.; Bravo, D.; Landete, J.M. Bacterial metabolism as responsible of beneficial effects of phytoestrogens on human health. Crit. Rev. Food Sci. Nutr. 2019, 60, 1922-1937. [CrossRef]

42. Sirerol, J.A.; Rodríguez, M.L.; Mena, S.; Asensi, M.A.; Estrela, J.M.; Ortega, A.L. Role of Natural Stilbenes in the Prevention of Cancer. Oxidative Med. Cell. Longev. 2015, 2016, 1-15. [CrossRef]

43. Nawaz, W.; Zhou, Z.; Deng, S.; Ma, X.; Ma, X.; Li, C.; Shu, X. Therapeutic Versatility of Resveratrol Derivatives. Nutrients 2017, 9, 1188. [CrossRef]

44. Berman, A.Y.; Motechin, R.A.; Wiesenfeld, M.Y.; Holz, M.K. The therapeutic potential of resveratrol: A review of clinical trials. NPJ Precis. Oncol. 2017, 1, 1-9. [CrossRef] [PubMed]

45. Xiao, Q.; Zhu, W.; Feng, W.; Lee, S.S.; Leung, A.W.; Shen, J.; Gao, L.; Xu, C. A Review of Resveratrol as a Potent Chemoprotective and Synergistic Agent in Cancer Chemotherapy. Front. Pharmacol. 2019, 9, 1534. [CrossRef] [PubMed]

46. Renaud, S.; De Lorgeril, M. Wine, alcohol, platelets, and the French paradox for coronary heart disease. Lancet 1992, 339, 1523-1526. [CrossRef]

47. Ko, J.-H.; Sethi, G.; Um, J.-Y.; Shanmugam, M.K.; Arfuso, F.; Kumar, A.P.; Bishayee, A.; Ahn, K.S. The Role of Resveratrol in Cancer Therapy. Int. J. Mol. Sci. 2017, 18, 2589. [CrossRef]

48. Leonard, S.S.; Xia, C.; Jiang, B.-H.; Stinefelt, B.; Klandorf, H.; Harris, G.K.; Shi, X. Resveratrol scavenges reactive oxygen species and effects radical-induced cellular responses. Biochem. Biophys. Res. Commun. 2003, 309, 1017-1026. [CrossRef]

49. Robb, E.L.; Stuart, J.A. Resveratrol interacts with estrogen receptor- $\beta$ to inhibit cell replicative growth and enhance stress resistance by upregulating mitochondrial superoxide dismutase. Free Radic. Biol. Med. 2011, 50, 821-831. [CrossRef]

50. Kampkötter, A.; Chovolou, Y.; Kulawik, A.; Röhrdanz, E.; Weber, N.; Proksch, P.; Wätjen, W. Isoflavone daidzein possesses no antioxidant activities in cell-free assays but induces the antioxidant enzyme catalase. Nutr. Res. 2008, 28, 620-628. [CrossRef]

51. Surico, D.; Ercoli, A.; Farruggio, S.; Raina, G.; Filippini, D.; Mary, D.; Minisini, R.; Surico, N.; Pirisi, M.; Grossini, E. Modulation of Oxidative Stress by $17 \beta$-Estradiol and Genistein in Human Hepatic Cell Lines In Vitro. Cell. Physiol. Biochem. 2017, 42, 1051-1062. [CrossRef]

52. Molina, L.; Bustamante, F.A.; Bhoola, K.D.; Figueroa, C.D.; Ehrenfeld, P. Possible role of phytoestrogens in breast cancer via GPER-1/GPR30 signaling. Clin. Sci. 2018, 132, 2583-2598. [CrossRef]

53. Rietjens, I.M.C.M.; Louisse, J.; Beekmann, K. The potential health effects of dietary phytoestrogens. Br. J. Pharmacol. 2017, 174, 1263-1280. [CrossRef]

54. Cappelletti, V.; Miodini, P.; Di Fronzo, G.; Daidone, M.G. Modulation of estrogen receptor- $\beta$ isoforms by phytoestrogens in breast cancer cells. Int. J. Oncol. 2006, 28, 1185-1191. [CrossRef] [PubMed]

55. Barnes, S. The Biochemistry, Chemistry and Physiology of the Isoflavones in Soybeans and their Food Products. Lymphat. Res. Biol. 2010, 8, 89-98. [CrossRef] [PubMed] 
56. Devi, K.P.; Rajavel, T.; Daglia, M.; Nabavi, S.M.; Bishayee, A. Targeting miRNAs by polyphenols: Novel therapeutic strategy for cancer. Semin. Cancer Biol. 2017, 46, 146-157. [CrossRef] [PubMed]

57. Bilal, I. Phytoestrogens and prevention of breast cancer: The contentious debate. World J. Clin. Oncol. 2014, 5, 705-712. [CrossRef]

58. Hsieh, C.-J.; Hsu, Y.-L.; Huang, Y.-F.; Tsai, E.-M. Molecular Mechanisms of Anticancer Effects of Phytoestrogens in Breast Cancer. Curr. Protein Pept. Sci. 2018, 19, 323-332. [CrossRef]

59. LeComte, S.; DeMay, F.; Ferrière, F.; Pakdel, F. Phytochemicals Targeting Estrogen Receptors: Beneficial Rather Than Adverse Effects? Int. J. Mol. Sci. 2017, 18, 1381. [CrossRef]

60. Eklund, P.C.; Långvik, O.K.; Wärnå, J.P.; Salmi, T.O.; Willför, S.M.; Sjöholm, R.E. Chemical studies on antioxidant mechanisms and free radical scavenging properties of lignans. Org. Biomol. Chem. 2005, 3, 3336-3347. [CrossRef]

61. Susanikova, I.; Puchl'ová, M.; Lachová, V.; Švajdlenka, E.; Muèaji, P.; Smetana, K.; Gál, P. Genistein and selected phytoestrogen-containing extracts differently modulate antioxidant properties and cell differentiation: An in vitro study in NIH-3T3, HaCaT and MCF-7 cells. Folia Biol. 2019, 65, 24-35.

62. Park, C.; Cha, H.-J.; Lee, H.; Hwangbo, H.; Ji, S.Y.; Kim, M.Y.; Hong, S.H.; Jeong, J.-W.; Han, M.H.; Choi, Y.H.; et al. Induction of G2/M Cell Cycle Arrest and Apoptosis by Genistein in Human Bladder Cancer T24 Cells through Inhibition of the ROS-Dependent PI3k/Akt Signal Transduction Pathway. Antioxidants 2019, 8, 327. [CrossRef]

63. Hsiao, Y.-C.; Peng, S.-F.; Lai, K.; Liao, C.-L.; Huang, Y.-P.; Lin, C.-C.; Lin, M.-L.; Liu, K.-C.; Tsai, C.-C.; Ma, Y.-S.; et al. Genistein induces apoptosis in vitro and has antitumor activity against human leukemia HL-60 cancer cell xenograft growth in vivo. Environ. Toxicol. 2019, 34, 443-456. [CrossRef]

64. Sanaei, M.; Kavoosi, F.; Atashpour, S.; Haghighat, S. Effects of Genistein and Synergistic Action in Combination with Tamoxifen on the HepG2 Human Hepatocellular Carcinoma Cell Line. Asian Pac. J. Cancer Prev. 2017, 18, 2381-2385.

65. Blanquer-Rosselló, M.D.M.; Hernández-López, R.; Roca, P.; Oliver, J.; Valle, A. Resveratrol induces mitochondrial respiration and apoptosis in SW620 colon cancer cells. Biochim. Biophys. Acta (BBA) Gen. Subj. 2017, 1861, 431-440.

66. Rodríguez-Enríquez, S.; Pacheco-Velázquez, S.C.; Marín-Hernández, Á.; Gallardo-Pérez, J.C.; Robledo-Cadena, D.X.; Hernández-Reséndiz, I.; García-García, J.D.; Belmont-Díaz, J.; López-Marure, R.; Hernández-Esquivel, L.; et al. Resveratrol inhibits cancer cell proliferation by impairing oxidative phosphorylation and inducing oxidative stress. Toxicol. Appl. Pharmacol. 2019, 370, 65-77. [CrossRef] [PubMed]

67. Blanquer-Rosselló, M.M.; Oliver, J.; Valle, A.; Roca, P. Effect of xanthohumol and 8-prenylnaringenin on MCF-7 breast cancer cells oxidative stress and mitochondrial complexes expression. J. Cell. Biochem. 2013, 114, 2785-2794. [CrossRef] [PubMed]

68. Sastre-Serra, J.; Ahmiane, Y.; Roca, P.; Oliver, J.; Pons, D.G. Xanthohumol, a hop-derived prenylflavonoid present in beer, impairs mitochondrial functionality of SW620 colon cancer cells. Int. J. Food Sci. Nutr. 2018, 70, 396-404. [CrossRef]

69. Zhang, B.; Chu, W.; Wei, P.; Liu, Y.; Wei, T. Xanthohumol induces generation of reactive oxygen species and triggers apoptosis through inhibition of mitochondrial electron transfer chain complex I. Free Radic. Biol. Med. 2015, 89, 486-497. [CrossRef] [PubMed]

70. Asslaber, D.; Grössinger, E.M.; Girbl, T.; Hofbauer, S.W.; Egle, A.; Weiss, L.; Greil, R.; Hartmann, T.N. Mimicking the microenvironment in chronic lymphocytic leukaemia-Where does the journey go? Br. J. Haematol. 2013, 160, 711-714. [CrossRef] [PubMed]

71. Bishayee, A.; Yerer-Aycan, M.B. Natural Products for Cancer Prevention and Therapy; MDPI: Basel, Switzerland, 2018.

72. Pons, D.G.; Nadal-Serrano, M.; Torrens-Mas, M.; Oliver, J.; Roca, P. The Phytoestrogen Genistein Affects Breast Cancer Cells Treatment Depending on the ER $\alpha / E R \beta$ Ratio. J. Cell. Biochem. 2015, 117, $218-229$. [CrossRef]

73. Sotoca, A.; Ratman, D.; Van Der Saag, P.; Ström, A.; Gustafsson, J.; Vervoort, J.; Rietjens, I.M.; Murk, A. Phytoestrogen-mediated inhibition of proliferation of the human T47D breast cancer cells depends on the ER $\alpha / E R \beta$ ratio. J. Steroid Biochem. Mol. Biol. 2008, 112, 171-178. [CrossRef] 
74. Pons, D.G.; Vilanova-Llompart, J.; Gaya-Bover, A.; Alorda-Clara, M.; Oliver, J.; Roca, P.; Sastre-Serra, J. The phytoestrogen genistein affects inflammatory-related genes expression depending on the ER $\alpha / E R \beta$ ratio in breast cancer cells. Int. J. Food Sci. Nutr. 2019, 70, 941-949. [CrossRef]

75. Le Marchand, L.; Murphy, S.P.; Hankin, J.H.; Wilkens, L.R.; Kolonel, L.N. Intake of Flavonoids and Lung Cancer. J. Natl. Cancer Inst. 2000, 92, 154-160. [CrossRef] [PubMed]

76. García-Closas, R.; Agudo, A.; González, C.A.; Riboli, E. Intake of specific carotenoids and flavonoids and the risk of lung cancer in women in Barcelona, Spain. Nutr. Cancer 1998, 32, 154-158. [CrossRef]

77. Garcia-Closas, R.; Gonzalez, C.A.; Agudo, A.; Riboli, E. Intake of specific carotenoids and flavonoids and the risk of gastric cancer in Spain. Cancer Causes Control 1999, 10, 71-75. [CrossRef] [PubMed]

78. Setiawan, V.W.; Zhang, Z.-F.; Yu, G.-P.; Lu, Q.-Y.; Li, Y.-L.; Lu, M.-L.; Wang, M.-R.; Guo, C.H.; Yu, S.-Z.; Kurtz, R.C.; et al. Protective effect of green tea on the risks of chronic gastritis and stomach cancer. Int. J. Cancer 2001, 92, 600-604. [CrossRef] [PubMed]

79. Rau, K.-M.; Kang, H.-Y.; Cha, T.-L.; A Miller, S.; Hung, M.-C. The mechanisms and managements of hormone-therapy resistance in breast and prostate cancers. Endocr. Relat. Cancer 2005, 12, 511-532. [CrossRef]

80. Van Duursen, M.B.M.; Nijmeijer, S.; De Morree, E.; De Jong, P.C.; Berg, M.V.D. Genistein induces breast cancer-associated aromatase and stimulates estrogen-dependent tumor cell growth in in vitro breast cancer model. Toxicology 2011, 289, 67-73. [CrossRef]

81. Constantinou, A.I.; White, B.E.; Tonetti, D.; Yang, Y.; Liang, W.; Li, W.; Van Breemen, R.B. The soy isoflavone daidzein improves the capacity of tamoxifen to prevent mammary tumours. Eur. J. Cancer 2005, 41, 647-654. [CrossRef]

82. Tonetti, D.A.; Zhang, Y.; Zhao, H.; Lim, S.-B.; Constantinou, A.I. The Effect of the Phytoestrogens Genistein, Daidzein, and Equol on the Growth of Tamoxifen-Resistant T47D/PKC $\alpha$. Nutr. Cancer 2007, 58, 222-229. [CrossRef]

83. Charalambous, C.; Constantinou, A.I. Abstract 577: Equol enhances tamoxifen's antitumor effect by induction of caspase-mediated apoptosis in MCF-7 breast cancer cells. Prev. Res. 2012, 72, 577.

84. Suh, Y.-A.; Jo, S.-Y.; Lee, H.-Y.; Lee, C. Inhibition of IL-6/STAT3 axis and targeting Axl and Tyro3 receptor tyrosine kinases by apigenin circumvent taxol resistance in ovarian cancer cells. Int. J. Oncol. 2014, 46, 1405-1411. [CrossRef]

85. Zhang, X.; Cook, K.L.; Warri, A.; Cruz, I.M.; Rosim, M.; Helferich, W.; Doerge, D.; Clarke, R.; Hilakivi-clarke, L. Lifetime genistein intake increases the response of mammary tumors to tamoxifen in rats. Clin. Cancer Res. 2017, 23, 814-824. [CrossRef]

86. Caley, A.; Jones, R. The principles of cancer treatment by chemotherapy. Surgery 2012, 30, 186-190. [CrossRef]

87. Huang, W.; Wan, C.; Luo, Q.-C.; Huang, Z.; Luo, Q. Genistein-Inhibited Cancer Stem Cell-Like Properties and Reduced Chemoresistance of Gastric Cancer. Int. J. Mol. Sci. 2014, 15, 3432-3443. [CrossRef] [PubMed]

88. Li, Y.; Ellis, K.-L.; Ali, S.; El-Rayes, B.F.; Nedeljkovic-Kurepa, A.; Kucuk, O.; Philip, P.A.; Sarkar, F.H. Apoptosis-Inducing Effect of Chemotherapeutic Agents Is Potentiated by Soy Isoflavone Genistein, a Natural Inhibitor of NF-kB in BxPC-3 Pancreatic Cancer Cell Line. Pancreas 2004, 28, 90-95. [CrossRef] [PubMed]

89. Belcher, S.M.; Burton, C.C.; Cookman, C.J.; Kirby, M.; Miranda, G.L.; Saeed, F.O.; Wray, K.E. Estrogen and soy isoflavonoids decrease sensitivity of medulloblastoma and central nervous system primitive neuroectodermal tumor cells to chemotherapeutic cytotoxicity. BMC Pharmacol. Toxicol. 2017, 18, 63. [CrossRef] [PubMed]

90. Hu, X.-J.; Jiang, L.; Kluxen, F.M.; Diel, P. Genistein modulates the anti-tumor activity of cisplatin in MCF-7 breast and HT-29 colon cancer cells. Arch. Toxicol. 2014, 88, 625-635. [CrossRef]

91. Aziz, N.; Froemming, G.; Kadir, S.; Ibrahim, M. Apigenin increases cisplatin inhibitory effects on the telomerase activity of triple negative breast cancer cells. J. Teknol. 2018, 80, 123-132. [CrossRef]

92. Caltagirone, S.; Rossi, C.; Poggi, A.; Ranelletti, F.; Natali, P.; Brunetti, M.; Aiello, F.; Piantelli, M. Flavonoids apigenin and quercetin inhibit melanoma growth and metastatic potential. Int. J. Cancer 2000, 87, 595-600. [CrossRef]

93. Santandreu, F.M.; Valle, A.; Oliver, J.; Roca, P. Resveratrol Potentiates the Cytotoxic Oxidative Stress Induced by Chemotherapy in Human Colon Cancer Cells. Cell. Physiol. Biochem. 2011, 28, 219-228. [CrossRef]

94. Aires, V.; Limagne, E.; Cotte, A.K.; Latruffe, N.; Ghiringhelli, F.; Delmas, D. Resveratrol metabolites inhibit human metastatic colon cancer cells progression and synergize with chemotherapeutic drugs to induce cell death. Mol. Nutr. Food Res. 2013, 57, 1170-1181. [CrossRef] 
95. Kuhar, M.; Sen, S.; Singh, N. Role of mitochondria in quercetin-enhanced chemotherapeutic response in human non-small cell lung carcinoma H-520 cells. Anticancer Res. 2006, 26, 1297-1303. [PubMed]

96. Sharma, H.; Sen, S.; Singh, N. Molecular pathways in the chemosensitization of cisplatin by quercetin in human head and neck cancer. Cancer Biol. Ther. 2005, 4, 949-955. [CrossRef] [PubMed]

97. Luo, H.; Daddysman, M.K.; Rankin, G.O.; Jiang, B.-H.; Chen, Y.C. Kaempferol enhances cisplatin's effect on ovarian cancer cells through promoting apoptosis caused by down regulation of cMyc. Cancer Cell Int. 2010, 10, 16. [CrossRef] [PubMed]

98. Ahmed, N.; Thompson, E.W.; Quinn, M.A. Epithelial-Mesenchymal Interconversions in Normal Ovarian Surface Epithelium and Ovarian Carcinomas: An Exception to the Norm. J. Cell Physiol. 2007, 207, 581-588. [CrossRef]

99. Lee, H.; Lee, D.; Kang, K.S.; Song, J.H.; Choi, Y.-K. Inhibition of Intracellular ROS Accumulation by Formononetin Attenuates Cisplatin-Mediated Apoptosis in LLC-PK1 Cells. Int. J. Mol. Sci. 2018, 19, 813. [CrossRef]

100. Suliman, F.A.; Khodeer, D.M.; Ibrahiem, A.; Mehanna, E.T.; El-Kherbetawy, M.K.; Mohammad, H.M.; Zaitone, S.A.; Moustafa, Y.M. Renoprotective effect of the isoflavonoid biochanin A against cisplatin induced acute kidney injury in mice: Effect on inflammatory burden and p53 apoptosis. Int. Immunopharmacol. 2018, 61, 8-19. [CrossRef]

101. Jazirehi, A.R.; Bonavida, B. Resveratrol modifies the expression of apoptotic regulatory proteins and sensitizes non-Hodgkin's lymphoma and multiple myeloma cell lines to paclitaxel-induced apoptosis. Mol. Cancer Ther. 2004, 3, 71-84.

102. Öztürk, Y.; Günaydın, C.; Yalçın, F.; Nazıroğlu, M.; Braidy, N. Resveratrol Enhances Apoptotic and Oxidant Effects of Paclitaxel through TRPM2 Channel Activation in DBTRG Glioblastoma Cells. Oxidative Med. Cell. Longev. 2019, 2019, 1-13. [CrossRef]

103. Stearns, M.E.; Wang, M. Synergistic Effects of the Green Tea Extract Epigallocatechin-3-gallate and Taxane in Eradication of Malignant Human Prostate Tumors. Transl. Oncol. 2011, 4, 147-156. [CrossRef]

104. Luo, T.; Wang, J.; Yin, Y.; Hua, H.; Jing, J.; Sun, X.; Li, M.; Zhang, Y.; Jiang, Y. (-)-Epigallocatechin gallate sensitizes breast cancer cells to paclitaxel in a murine model of breast carcinoma. Breast Cancer Res. 2010, 12, R8. [CrossRef]

105. Krajnović, T.T.; Kaluđerović, G.N.; Wessjohann, L.; Mijatovic, S.A.; Maksimovic-Ivanic, D. Versatile antitumor potential of isoxanthohumol: Enhancement of paclitaxel activity in vivo. Pharmacol. Res. 2016, 105, 62-73. [CrossRef] [PubMed]

106. Wu, S.-L.; Sun, Z.-J.; Yu, L.; Meng, K.-W.; Qin, X.-L.; Pan, C.-E. Effect of resveratrol and in combination with 5-FU on murine liver cancer. World J. Gastroenterol. 2004, 10, 3048-3052. [CrossRef]

107. Lee, S.H.; Koo, B.S.; Park, S.Y.; Kim, Y.M. Anti-angiogenic effects of resveratrol in combination with 5-fluorouracil on B16 murine melanoma cells. Mol. Med. Rep. 2015, 12, 2777-2783. [CrossRef] [PubMed]

108. Harikumar, K.B.; Kunnumakkara, A.B.; Sethi, G.; Diagaradjane, P.; Anand, P.; Pandey, M.K.; Gelovani, J.; Krishnan, S.; Guha, S.; Aggarwal, B.B. Resveratrol, a multitargeted agent, can enhance antitumor activity of gemcitabinein vitroand in orthotopic mouse model of human pancreatic cancer. Int. J. Cancer 2010, 127, 257-268. [CrossRef] [PubMed]

109. Frampton, G.; Lazcano, E.; Li, H.; Mohamad, A.; DeMorrow, S. Resveratrol enhances the sensitivity of cholangiocarcinoma to chemotherapeutic agents. Lab. Investig. 2010, 90, 1325-1338. [CrossRef] [PubMed]

110. Zhang, B.; Shi, Z.-L.; Liu, B.; Yan, X.-B.; Feng, J.; Tao, H.-M. Enhanced anticancer effect of gemcitabine by genistein in osteosarcoma: The role of Akt and nuclear factor-kB. Anti-Cancer Drugs 2010, 21, 288-296. [CrossRef]

111. Solomon, L.; Ali, S.; Banerjee, S.; Munkarah, A.; Morris, R.T.; Sarkar, F.H. Sensitization of ovarian cancer cells to cisplatin by genistein: The role of NF-kappaB. J. Ovarian Res. 2008, 1, 9. [CrossRef]

112. Banerjee, S.; Zhang, Y.; Ali, S.; Bhuiyan, M.; Wang, Z.; Chiao, P.J.; Philip, P.A.; Abbruzzese, J.; Sarkar, F.H. Molecular Evidence for Increased Antitumor Activity of Gemcitabine by GenisteinIn vitroandIn vivoUsing an Orthotopic Model of Pancreatic Cancer. Cancer Res. 2005, 65, 9064-9072. [CrossRef]

113. Suzuki, R.; Kang, Y.; Li, X.; Roife, D.; Zhang, R.; Fleming, J.B. Genistein potentiates the antitumor effect of 5 -fluorouracil by inducing apoptosis and autophagy in human pancreatic cancer cells. Anticancer Res. 2014, $34,4685-4692$. 
114. Tang, S.-N.; Fu, J.; Shankar, S.; Srivastava, R. EGCG Enhances the Therapeutic Potential of Gemcitabine and CP690550 by Inhibiting STAT3 Signaling Pathway in Human Pancreatic Cancer. PLoS ONE 2012, 7, e31067. [CrossRef]

115. Guo, J.; Wang, Q.; Zhang, Y.; Sun, W.; Zhang, S.; Li, Y.; Wang, J.; Bao, Y. Functional daidzein enhances the anticancer effect of topotecan and reverses BCRP-mediated drug resistance in breast cancer. Pharmacol. Res. 2019, 147, 104387. [CrossRef] [PubMed]

116. Rigalli, J.P.; Tocchetti, G.N.; Arana, M.R.; Villanueva, S.S.M.; Catania, V.A.; Theile, D.; Ruiz, M.L.; Weiss, J. The phytoestrogen genistein enhances multidrug resistance in breast cancer cell lines by translational regulation of ABC transporters. Cancer Lett. 2016, 376, 165-172. [CrossRef] [PubMed]

117. Farjadian, S.; Khajoei, N.; Fazeli, M.; Askari, F. Doxorubicin cytotoxicity in combination with diadzein on MCF-7 Breast Cancer Cells. Malays. J. Nutr. 2015, 21, 67-73.

118. Xue, J.-P.; Wang, G.; Zhao, Z.-B.; Wang, Q.; Shi, Y. Synergistic cytotoxic effect of genistein and doxorubicin on drug-resistant human breast cancer MCF-7/Adr cells. Oncol. Rep. 2014, 32, 1647-1653. [CrossRef]

119. Stearns, M.E.; Amatangelo, M.D.; Varma, D.; Sell, C.; Goodyear, S.M. Combination Therapy with Epigallocatechin-3-Gallate and Doxorubicin in Human Prostate Tumor Modeling Studies. Am. J. Pathol. 2010, 177, 3169-3179. [CrossRef]

120. Reedijk, M.; Odorcic, S.; Zhang, H.; Chetty, R.; Tennert, C.; Dickson, B.C.; Lockwood, G.; Gallinger, S.; Egan, S.E. Green tea catechins augment the antitumor activity of doxorubicin in an in vivo mouse model for chemoresistant liver cancer. Int. J. Hyperth 2009, 33, 1223-1229.

121. Du, G.; Song, Z.-H.; Lin, H.; Han, X.-F.; Zhang, S.; Yang, Y.-M. Luteolin as a glycolysis inhibitor offers superior efficacy and lesser toxicity of doxorubicin in breast cancer cells. Biochem. Biophys. Res. Commun. 2008, 372, 497-502. [CrossRef]

122. Staedler, D.; Idrizi, E.; Kenzaoui, B.H.; Juillerat-Jeanneret, L. Drug combinations with quercetin: Doxorubicin plus quercetin in human breast cancer cells. Cancer Chemother. Pharmacol. 2011, 68, 1161-1172. [CrossRef]

123. Sharma, V.; Joseph, C.; Ghosh, S.; Agarwal, A.; Mishra, M.K.; Sen, E. Kaempferol induces apoptosis in glioblastoma cells through oxidative stress. Mol. Cancer Ther. 2007, 6, 2544-2553. [CrossRef]

124. Kweon, S.H.; Song, J.H.; Kim, T.S. Resveratrol-mediated reversal of doxorubicin resistance in acute myeloid leukemia cells via downregulation of MRP1 expression. Biochem. Biophys. Res. Commun. 2010, 395, 104-110. [CrossRef]

125. Liu, Q.; Sun, Y.; Zheng, J.-M.; Yan, X.-L.; Chen, H.-M.; Chen, J.-K.; Huang, H.-Q. Formononetin sensitizes glioma cells to doxorubicin through preventing EMT via inhibition of histone deacetylase 5. Int. J. Clin. Exp. Pathol. 2015, 8, 6434-6441. [PubMed]

126. Hsu, Y.-N.; Shyu, H.-W.; Hu, T.-W.; Yeh, J.-P.; Lin, Y.-W.; Lee, L.-Y.; Yeh, Y.-T.; Dai, H.-Y.; Perng, D.-S.; Su, S.-H.; et al. Anti-proliferative activity of biochanin A in human osteosarcoma cells via mitochondrial-involved apoptosis. Food Chem. Toxicol. 2018, 112, 194-204. [CrossRef]

127. Dash, T.K.; Konkimalla, V.B. Formulation and Optimization of Doxorubicin and Biochanin A Combinational Liposomes for Reversal of Chemoresistance. AAPS PharmSciTech 2016, 18, 1116-1124. [CrossRef] [PubMed]

128. Wang, G.; Zhang, D.; Yang, S.; Wang, Y.; Tang, Z.; Fu, X. Co-administration of genistein with doxorubicin-loaded polypeptide nanoparticles weakens the metastasis of malignant prostate cancer by amplifying oxidative damage. Biomater. Sci. 2018, 6, 827-835. [CrossRef] [PubMed]

129. Lo, Y.-L. A Potential Daidzein Derivative Enhances Cytotoxicity of Epirubicin on Human Colon Adenocarcinoma Caco-2 Cells. Int. J. Mol. Sci. 2012, 14, 158-176. [CrossRef]

130. Somjen, D.; Katzburg, S.; Nevo, N.; Gayer, B.; Hodge, R.P.; Renevey, M.D.; Kalchenko, V.; Meshorer, A.; Stern, N.; Kohen, F. A daidzein-daunomycin conjugate improves the therapeutic response in an animal model of ovarian carcinoma. J. Steroid Biochem. Mol. Biol. 2008, 110, 144-149. [CrossRef] [PubMed]

131. Du, R.; Liu, Z.; Hou, X.; Fu, G.; An, N.; Wang, L. Trichostatin A potentiates genistein-induced apoptosis and reverses EMT in HEp2 cells. Mol. Med. Rep. 2016, 13, 5045-5052. [CrossRef] [PubMed]

132. Shiau, R.-J.; Chen, K.-Y.; Wen, Y.-D.; Chuang, C.-H.; Yeh, S.-L. Genistein and $\beta$-carotene enhance the growth-inhibitory effect of trichostatin A in A549 cells. Eur. J. Nutr. 2009, 49, 19-25. [CrossRef]

133. Vanneman, M.; Dranoff, G. Combining immunotherapy and targeted therapies in cancer treatment. Nat. Rev. Cancer 2012, 12, 237-251. [CrossRef] 
134. Li, S.; Li, J.; Dai, W.; Zhang, Q.; Feng, J.; Wu, L.; Liu, T.; Yu, Q.; Xu, S.; Wang, W.; et al. Genistein suppresses aerobic glycolysis and induces hepatocellular carcinoma cell death. Br. J. Cancer 2017, 117, 1518-1528. [CrossRef]

135. Rigalli, J.P.; Ciriaci, N.; Arias, A.; Ceballos, M.P.; Villanueva, S.S.M.; Luquita, M.G.; Mottino, A.D.; Ghanem, C.I.; Catania, V.A.; Ruiz, M.L. Regulation of Multidrug Resistance Proteins by Genistein in a Hepatocarcinoma Cell Line: Impact on Sorafenib Cytotoxicity. PLoS ONE 2015, 10, e0119502. [CrossRef] [PubMed]

136. Ivanova, D.; Zhelev, Z.; Semkova, S.; Aoki, I.; Bakalova, R. Resveratrol Modulates the Redox-status and Cytotoxicity of Anticancer Drugs by Sensitizing Leukemic Lymphocytes and Protecting Normal Lymphocytes. Anticancer Res. 2019, 39, 3745-3755. [CrossRef] [PubMed]

137. Mondal, A.; Bennett, L.L. Resveratrol enhances the efficacy of sorafenib mediated apoptosis in human breast cancer MCF7 cells through ROS, cell cycle inhibition, caspase 3 and PARP cleavage. Biomed. Pharmacother. 2016, 84, 1906-1914. [CrossRef] [PubMed]

138. Youssef, M.M.; Tolba, M.F.; Badawy, N.N.; Liu, A.W.; El-Ahwany, E.; Khalifa, A.E.; Zada, S.; Abdel-Naim, A.B. Novel combination of sorafenib and biochanin-A synergistically enhances the anti-proliferative and pro-apoptotic effects on hepatocellular carcinoma cells. Sci. Rep. 2016, 6, 30717. [CrossRef] [PubMed]

139. Wu, X.Y.; Xu, H.; Wu, Z.F.; Chen, C.; Liu, J.Y.; Wu, G.N.; Yao, X.Q.; Liu, F.K.; Liang, S.; Shen, L. Formononetin, a novel FGFR2 inhibitor, potently inhibits angiogenesis and tumor growth in preclinical models. Oncotarget 2015, 6, 44563-44578. [CrossRef]

140. Shao, H.; Jing, K.; Mahmoud, E.; Huang, H.; Fang, X.; Yu, C. Apigenin Sensitizes Colon Cancer Cells to Antitumor Activity of ABT-263. Mol. Cancer Ther. 2013, 12, 2640-2650. [CrossRef] [PubMed]

141. Stanisic, D.; Costa, A.F.; Cruz, G.; Durán, N.; Tasic, L. Applications of Flavonoids, With an Emphasis on Hesperidin, as Anticancer Prodrugs: Phytotherapy as an Alternative to Chemotherapy. Stud. Nat. Prod. Chem. 2018, 58, 161-212.

142. Singh, Y.; Palombo, M.; Sinko, P. Recent Trends in Targeted Anticancer Prodrug and Conjugate Design. Curr. Med. Chem. 2008, 15, 1802-1826. [CrossRef]

143. Arroo, R.R.J.; Androutsopoulos, V.P.; Patel, A.; Surichan, S.; Wilsher, N.; Potter, G.A. Phytoestrogens as natural prodrugs in cancer prevention: A novel concept. Phytochem. Rev. 2008, 7, 431-443. [CrossRef]

144. Arroo, R.R.J.; Androutsopoulos, V.P.; Beresford, K.; Ruparelia, K.; Surichan, S.; Wilsher, N.; Potter, G.A. Phytoestrogens as natural prodrugs in cancer prevention: Dietary flavonoids. Phytochem. Rev. 2009, 8, 375-386. [CrossRef]

145. Ruparelia, K.C.; Zeka, K.; Ijaz, T.; Ankrett, D.N.; Wilsher, N.E.; Butler, P.C.; Tan, H.L.; Lodhi, S.; Bhambra, A.S.; Potter, G.A.; et al. The Synthesis of Chalcones as Anticancer Prodrugs and their Bioactivation in CYP1 Expressing Breast Cancer Cells. Med. Chem. 2018, 14, 322-332. [CrossRef] [PubMed]

146. Biasutto, L.; Zoratti, M. Prodrugs of quercetin and resveratrol: A strategy under development. Curr. Drug Metab. 2014, 15, 77-95. [CrossRef] [PubMed]

147. Biasutto, L.; Mattarei, A.; Sassi, N.; Azzolini, M.; Romio, M.; Paradisi, C.; Zoratti, M. Improving the efficacy of plant polyphenols. Anti-Cancer Agents Med. Chem. 2014, 14, 1332-1342. [CrossRef] [PubMed]

148. Wang, Y.R.; Wigington, D.P.; Strugnell, S.A.; Knutson, J.C. Growth inhibition of cancer cells by an active metabolite of a novel vitamin D prodrug. Anticancer Res. 2005, 25, 4333-4339.

149. Appel, E.; Rabinkov, A.; Neeman, M.; Kohen, F.; Mirelman, D. Conjugates of daidzein-alliinase as a targeted pro-drug enzyme system against ovarian carcinoma. J. Drug Target. 2010, 19, 326-335. [CrossRef]

150. Di, Y.; Ji, S.; Wolf, P.; Krol, E.S.; Alcorn, J. Enterolactone glucuronide and $\beta$-glucuronidase in antibody directed enzyme prodrug therapy for targeted prostate cancer cell treatment. AAPS PharmSciTech 2017, 18, 2336-2345. [CrossRef]

151. Hsieh, C.-Y.; Ko, P.-W.; Chang, Y.-J.; Kapoor, M.; Liang, Y.-C.; Chu, H.-L.; Lin, H.-H.; Horng, J.-C.; Hsu, M.-H. Design and Synthesis of Benzimidazole-Chalcone Derivatives as Potential Anticancer Agents. Molecules 2019, 24, 3259. [CrossRef]

152. El-Rayes, B.F.; Philip, P.A.; Sarkar, F.H.; Shields, A.F.; Ferris, A.M.; Hess, K.; Kaseb, A.O.; Javle, M.M.; Varadhachary, G.R.; Wolff, R.A.; et al. A phase II study of isoflavones, erlotinib, and gemcitabine in advanced pancreatic cancer. Investig. New Drugs 2010, 29, 694-699. [CrossRef] 
153. Löhr, J.-M.; Karimi, M.; Omazic, B.; Kartalis, N.; Verbeke, C.S.; Berkenstam, A.; Frödin, J.-E. A phase I dose escalation trial of AXP107-11, a novel multi-component crystalline form of genistein, in combination with gemcitabine in chemotherapy-naive patients with unresectable pancreatic cancer. Pancreatology 2016, 16, 640-645. [CrossRef]

154. Yahyapour, R.; Motevaseli, E.; Rezaeyan, A.; Abdollahi, H.; Farhood, B.; Cheki, M.; Najafi, M.; Villa, V. Mechanisms of Radiation Bystander and Non-Targeted Effects: Implications to Radiation Carcinogenesis and Radiotherapy. Curr. Radiopharm. 2018, 11, 34-45. [CrossRef]

155. Kim, I.G.; Kim, J.S.; Lee, J.H.; Cho, E.W. Genistein decreases cellular redox potential, partially suppresses cell growth in HL-60 leukemia cells and sensitizes cells to $\gamma$-radiation-induced cell death. Mol. Med. Rep. 2014, 10, 2786-2792. [CrossRef] [PubMed]

156. Tang, Q.; Ma, J.; Sun, J.; Yang, L.; Yang, F.; Zhang, W.; Li, R.; Wang, L.; Wang, Y.; Wang, H. Genistein and AG1024 synergistically increase the radiosensitivity of prostate cancer cells. Oncol. Rep. 2018, 40, 579-588. [PubMed]

157. Raffoul, J.J.; Banerjee, S.; Che, M.; Knoll, Z.E.; Doerge, D.R.; Abrams, J.; Kucuk, O.; Sarkar, F.H.; Hillman, G.G. Soy isoflavones enhance radiotherapy in a metastatic prostate cancer model. Int. J. Cancer 2007, 120, 2491-2498. [CrossRef] [PubMed]

158. Johnson, G.E.; Ivanov, V.N.; Hei, T.K. Radiosensitization of melanoma cells through combined inhibition of protein regulators of cell survival. Apoptosis 2008, 13, 790-802. [CrossRef]

159. Scarlatti, F.; Sala, G.; Ricci, C.; Maioli, C.; Milani, F.; Minella, M.; Botturi, M.; Ghidoni, R. Resveratrol sensitization of DU145 prostate cancer cells to ionizing radiation is associated to ceramide increase. Cancer Lett. 2007, 253, 124-130. [CrossRef]

160. Baatout, S.; Derradji, H.; Jacquet, P.; Ooms, D.; Michaux, A.; Mergeay, M. Enhanced radiation-induced apoptosis of cancer cell lines after treatment with resveratrol. Int. J. Mol. Med. 2004, 13, 895-902. [CrossRef]

161. Zoberi, I.; Bradbury, C.; Curry, H.A.; Bisht, K.S.; Goswami, P.C.; Roti, J.L.R.; Gius, D. Radiosensitizing and anti-proliferative effects of resveratrol in two human cervical tumor cell lines. Cancer Lett. 2002, 175, 165-173. [CrossRef]

162. Manna, K.; Das, U.; Das, D.; Kesh, S.B.; Khan, A.; Chakraborty, A.; Dey, S. Naringin inhibits gamma radiation-induced oxidative DNA damage and inflammation, by modulating p53 and NF- $\mathrm{B}$ signaling pathways in murine splenocytes. Free Radic. Res. 2015, 49, 422-439. [CrossRef]

Publisher's Note: MDPI stays neutral with regard to jurisdictional claims in published maps and institutional affiliations.

(C) 2020 by the authors. Licensee MDPI, Basel, Switzerland. This article is an open access article distributed under the terms and conditions of the Creative Commons Attribution (CC BY) license (http://creativecommons.org/licenses/by/4.0/). 